Article

\title{
Transitions between Centralization and Metapolization: From City Development Strategy (CDS) to Peri-Urban Development Strategy (PDS)
}

\author{
Sedigheh Asefi ${ }^{1, *(\mathbb{D})}$, João Matias ${ }^{1}\left(\mathbb{D}\right.$ and Carlos Gonçalves ${ }^{2}$ (1) \\ 1 Departamento de Economia, Gestão, Engenharia Industrial e Turismo, Aveiro University, \\ 3810-193 Aveiro, Portugal; jmatias@ua.pt \\ 2 Departamento de Ciências Sociais, Políticas e do Território, Aveiro University, 3810-193 Aveiro, Portugal; \\ carlosgoncalves@ua.pt \\ * Correspondence: Asefi@ua.pt
}

Received: 14 November 2020; Accepted: 10 December 2020; Published: 20 December 2020

\begin{abstract}
The elaboration of City Development Strategies (CDS) helps cities to harness the potential of urbanization through strategic planning, and consequently to contribute to promoting development, balancing city growth, and empowering citizens. Continuous and sprawling development along with peri-urban areas has offered a vast and almost limitless nexus of villages-towns upon which the intensifying needs of development, initiatives, and infrastructures can be grafted. Considering the significant role of constructed nexuses in growth and resilience, and thus in planning for the sustainable development of such urban-rural areas, this study will advance the development of a model of the Urban-Rural Reef ecosystem through discovering its main attributes. In doing so, Aveiro has been distinguished as an urban-rural reef to describe such a case study's characteristics and to extract the indicators of peri-urban sustainable development strategies. In the next step, the assessment of the peri-urban development strategy (PDS) has been accomplished by using the Multi-Criteria Decision Analysis (MCDM) method and applying the Analytic Hierarchy Process (AHP) approach. Finally, a conclusion has been presented based on the findings for Aveiro urban-rural reefs containing the analysis results and offering some solutions.
\end{abstract}

Keywords: peri-urban interface; rugosity; urban-rural reef; peri-urban development strategy (PDS)

\section{Introduction}

Over the past decades, influenced by the rapid population growth, social-spatial landscapes and global environment changes, the urban sprawl has sped up [1,2]. In this context, peri-urban areas have been made to respond to unprecedented economic, social, and environmental challenges [3]. Consequentially, new, and innovative urban planning approaches are needed to achieve a more sustainable pattern of this kind of urbanization. In essence, the scope of the recent urban planning approaches has been modified from concentrating on the development of a city's value-added characteristics [4] towards a multidisciplinary perspective and mutually profitable framework from stakeholders engaged in the peri-urban transformation, where conflicts between development priorities are inevitable.

Moreover, these factors compel cities to face the social exclusion and disabilities of its peri-urban crowns, maintaining the physical attractiveness, fighting against environmental degradation, improving farming production and, in this way, boosting their significant role in countries' food security, growingly in recent years [5]. Urban planning has to face complicated challenges of socioeconomic inequalities, taking advantage of shared urban-rural metabolism and maximizing peri-urban interfaces (PUIs) [6]. 
The importance of dynamic inter-linkages of social-ecological systems in PUIs has been widely studied in order to understand the challenges posed to the sustainable urban development [7-10]. However, the significance of urban forms and their shared metabolism within the higher structural complexity of PUIs through which services and goods are absorbed in a more sustained ecosystem is a rather neglected topic. The role of maximizing the urban interface in providing increased growth and resilience through building nutrient exchanges with the farm-city shared metabolism has been recently admitted within fringe theories [11]. To estimate the structural complexity degree at the urban interface, a rugosity spatial indicator, drawing from coral reef topographies, was coined by Brinkley (2018), within her research "Cities as Coral Reefs", in which vibrant economic growth and resilience are expected within higher rugosity. As complex nexuses of coral reefs aggregate nutrient resources, rugosity allows us to understand a specific region with greater metabolic exchanges in an urban-rural reef. In general, these regions contain over half of the population in only two percent of the land and, even so, these areas produce significant amounts of food [12,13].

Promoting urban development strategies in such a complex PUIs is only possible through inter-sectional coordination and communication, and with the participation of all stakeholders, as well as all the subsystems that are representative of metabolic flows (capital, material and energy). The integration of sustainable development will be fostered if the local government can find a balance between promoting economic competitiveness, managing population growth, solving social problems (urban poverty, unemployment), and facing environmental challenges towards local sustainable participatory strategies [14]. Therefore, peri-urban development strategies (PDS) reflect a multidisciplinary and a mutualistic collaborated approach that encompasses diverse components in an inter-sectional matrix of interactions, in order to improve stakeholders' capability of nutrient exchange and to more efficiently manage the city and its surrounding environment.

To create the tradeoff system that links economic, environmental and social urban systems (named sustainable urbanization), CDS has been adopted by Cities Alliance Organizations as an emerging approach to the strategic urban planning [15]. The CDS framework comprised a set of indicators used to evaluate the sustainability of city policies throughout the planning cycle (ex-ante, ongoing, ex-post phases). The evaluation of strategic urban plans using a set of indicators will enable the achievement of the sustainable goals in engaged cities. This kind of framework will contribute to a more comprehensive vision of PDS and help to find objectivity-correlated strategic urban plans.

Therefore, in the next sections we will focus on three main objectives: (i) select and describe a city-region with high structural peri-urban complexity; (ii) identify indicators and indexes of sustainability in previous and current studies in the city-region's case-studies, providing an analysis based on the Analytic Hierarchy Process (AHP) approach; (iii) evaluate the level of sustainability achieved in this city-region. In this regard, Aveiro County has been selected as case study. We will analyze, evaluate, and finally provide some suggestions for better managing the PDS. This will allow us to suggest improvements to urban planning approaches (namely in CDSs) to better achieve its special needs through local stockholder's partnerships, and to foster adaptive PDS.

\section{From CDS to PDS: A Concentric and Inter-Sectional Strategic Scope}

For many centuries, agricultural settlements have been transformed by urban drivers, shifting the rural land uses to other human activities and socio-ecosystems. Gradually, human civilization has been shaped by urbanization, where all human and natural-led systems are tightly connected, creating more and more complex systems of infrastructures, where people, materials, information, capital and energy circulate [16]. This resulted in global urban networks that combine terrestrial and aquatic ecosystems, which is called anthroposphere. These ecosystems evolve through a series anthropogenic dynamic material flow, whose properties and functions change in space and with time. Hence, the future of the anthroposphere will be decided by the urbanization drivers, where the mechanisms to manage growth and to reinforce environmental quality stand out [17]. 
In the 21st century, advancing human habitat development toward expanding the artificial land use, population change, and peri-urban growth (the anthroposphere) has regained ground, improving our understanding and the capacity to preserve and to manage the quality of the transformations of such habitats $[16,18,19]$. However, the evidence shows that in this progress, the main advances were achieved through acting separately in the ecosystems' components. Components (including environment, community of stakeholders and financial issues) were gauged to manage the performance of different factors and not to integrate the multiple dimensions of the sustainable development. Therefore, in establishing development strategies as holistic integrative approaches, putting together relevant disciplines may intensify multiple benefits across the social, environmental, and economic dimensions, avoiding the compartmentalization trap in development [20].

Due to rapid advancing urbanization into the urban sprawl, the Agenda for Sustainable Development has become the main challenge when planning governance systems that have to construct, implement and evaluate national, regional and urban strategies. The peri-urbanization phenomenon has exacerbated the inequities of accessibility to the resources that support the residents' quality-of-life, both in the city and in surrounding areas. Hence, the development of peri-urban areas lays the foundation for adopting new approaches to city-region planning, in which city and regional plans are more able to implement efficient integrated agendas.

\subsection{From Inward-Looking to Outward-Looking}

In the early 19th century, the concentric city model was orientated by the city center as a unique business district through a mono-hub of all available employment, goods, and services surrounded by nurturing offices [21]. Thereby, the most productive activities, which create added value from rural land uses around the city center, were constrained by transport costs and needed to be closer to the city centers to access the urban markets [22]. Urban planning had valorized the highest land values, inflating the city centers, and regarded the city's periphery as land without value, giving little attention to the environmental protection, social equity, and place-based economic development [11,23].

Due to the unstoppable urbanization process, the dominant position of cities as regional nodes was dropped to diverse urban regions that maintain their self-subsidiarity and improve the capacity to compete with urban areas. Aligned with the journey from evolving industrial cities to increasingly complex cities, rapid social and economic development has put serious pressure on the urban areas, leading to further urban land-use (suburbanization) for economic growth, housing, population growth and transportation, and consequently an outward-looking growth of urban sprawl [24-26]. These have caused unprecedented challenges in the first half of the 21st century, in which cities will face inevitable social problems, economic uncertainties, lack of financial resources and various restrictions imposed on local governments. To respond to these contemporary urban challenges, CDS has been performed as an innovative approach in which the coordination between development ideals and executive plans has led it to become an adaptive framework.

The main target of the CDS is to create development strategies that unify the pillars of sustainability (society, economy, and environment) and simultaneously provide integrative planning through specific issues for cities, such as poverty reduction, sustainable urban development, environmental sustainability, and economic growth. Specific actions' priorities and investments regarding the city's vision are defined by local stakeholders to maximize their cities' potential. This could be measured by improvements in the quality of life (especially for the poor), the competitiveness, and the resilience [27].

The Cities Alliance, including the World Development Bank, the United Nations and the Asian Development Bank, and other important financial organizations, are a global movement of cities involved in the CDS approach. The main goals are helping to promote this planning approach in order to provide the abilities required to face the challenges of globalization, to foster decentralization and to achieve positive social and economic conditions for all [28].

In general, the Cities Alliance develops sustainable financing strategies, helps local authorities to plan for growth and supports local governments in long-term investments. Drawing upon the various 
CDS experiences of approximately 200 countries around the world with different degrees of success, Cities Alliance proposed five CDS thematic dimensions: livelihood, environmental sustainability, urban form and an infrastructure's network, financial resources, and governance. These thematic dimensions form its building blocks in providing a more comprehensive understanding of CDS, its implementing process in cities, the management of unpredictable challenges and the achievement of their goals (Table 1).

Table 1. City Development Strategies (CDS) topics defined by Cities Alliance.

\begin{tabular}{|c|c|c|}
\hline Issue & Defined Context & Thematic Issues \\
\hline \multirow{3}{*}{ Livelihood } & $\begin{array}{l}\text { Business climate and capacity } \\
\text { for creating small business }\end{array}$ & $\begin{array}{l}\text { Incentives offered by the local } \\
\text { jurisdiction; nuisance taxation; ease of } \\
\text { starting a business; investment } \\
\text { approval processes for foreign firms } \\
\text { and joint ventures; operating } \\
\text { environment of informal sector; } \\
\text { government attitudes towards the } \\
\text { informal sector }\end{array}$ \\
\hline & Urban competitiveness & $\begin{array}{l}\text { Basic economic trends; diversity } \\
\text { versus specialization; national and } \\
\text { world-class economic activities; } \\
\text { productivity gains ; economic mix and } \\
\text { change; movement up the value chain } \\
\text { and cluster deepening ; rate of } \\
\text { start-ups and business deaths; foreign } \\
\text { direct investment, innovation; } \\
\text { performance of anchor firms; } \\
\text { labor market } \\
\text { Marketing and promotion; } \\
\text { attracting talent }\end{array}$ \\
\hline & Human resource development & $\begin{array}{l}\text { Educational quality and quantity; } \\
\text { education-economic alignment; access } \\
\text { to education; financial support to } \\
\text { students; access to entry-level jobs; } \\
\text { geographic accessibility to } \\
\text { labor market }\end{array}$ \\
\hline \multirow{3}{*}{ Environmental Sustainability } & Environmental quality & $\begin{array}{l}\text { Air pollution; wastewater and water } \\
\text { quality; pollution sources; } \\
\text { sustainability and safety of water } \\
\text { supply; loss of agricultural and } \\
\text { environmentally sensitive land; } \\
\text { amenity; natural hazards }\end{array}$ \\
\hline & Service delivery & $\begin{array}{l}\text { Demand for services; delivery of basic } \\
\text { needs; health, education, and literacy } \\
\text { status; quality of basic services; } \\
\text { delivery of services to migrants; } \\
\text { public health; efficiency in delivery of } \\
\text { environmental infrastructure; } \\
\text { maintenance; energy and } \\
\text { environmental policy frameworks }\end{array}$ \\
\hline & Energy efficiency & $\begin{array}{c}\text { Energy consumption; urban form and } \\
\text { energy consumption; } \\
\text { demand management }\end{array}$ \\
\hline
\end{tabular}


Table 1. Cont.

\begin{tabular}{|c|c|c|}
\hline Issue & Defined Context & Thematic Issues \\
\hline \multirow[b]{2}{*}{$\begin{array}{l}\text { Infrastructure and its role in } \\
\text { welfare and } \\
\text { economic competitiveness }\end{array}$} & Infrastructure & $\begin{array}{l}\text { Infrastructure delivery performance; } \\
\text { infrastructure delivery modes; } \\
\text { planned infrastructure; trunk } \\
\text { infrastructure and urban form; } \\
\text { housing supply and demand; } \\
\text { affordable land and housing; } \\
\text { transportation networks; public } \\
\text { transportation facilities and services; } \\
\text { urban nodes and public transport } \\
\text { demand; major transportation } \\
\text { facilities; movement of goods; } \\
\text { telecommunication services }\end{array}$ \\
\hline & $\begin{array}{l}\text { Urban form to access the urban } \\
\text { service and facilities }\end{array}$ & $\begin{array}{l}\text { Formal and informal spaces; urban } \\
\text { density; land and property value } \\
\text { gradients; land and housing markets; } \\
\text { monocentric versus; peri-urban spatial } \\
\text { form; location of the service economy; } \\
\text { spatial distribution of employment } \\
\text { and economic output; social } \\
\text { geography; geography of poverty; } \\
\text { location of slums and squatter areas; } \\
\text { land readjustment; destination of } \\
\text { migrants; geography of investment; } \\
\text { congestion; the knowledge-economy; } \\
\text { expansion vectors; street life, } \\
\text { entertainment, and recreation }\end{array}$ \\
\hline \multirow{3}{*}{ Financial Resources } & $\begin{array}{l}\text { Local development financial } \\
\text { absorbs and } \\
\text { institutional structures }\end{array}$ & $\begin{array}{l}\text { Local government budgets; local } \\
\text { government revenues; capital } \\
\text { planning; off-budget revenue and } \\
\text { expenditures; transfers overtime; } \\
\text { extent and impacts of decentralization; } \\
\text { debt; access to credit; credit rating; } \\
\text { autonomous bodies }\end{array}$ \\
\hline & $\begin{array}{l}\text { Mobilizing nongovernment } \\
\text { capital }\end{array}$ & $\begin{array}{l}\text { Impact of land readjustment; impact } \\
\text { of land tenure; housing credit; } \\
\text { financing local infrastructure; } \\
\text { microfinance; credit for small- and } \\
\text { medium-size enterprises; voluntary } \\
\text { organization finance }\end{array}$ \\
\hline & Private sector financial flows & $\begin{array}{c}\text { Foreign direct investment; domestic } \\
\text { investment; Commercial } \\
\text { banking flows }\end{array}$ \\
\hline
\end{tabular}


Table 1. Cont.

\begin{tabular}{|c|c|c|}
\hline Issue & Defined Context & Thematic Issues \\
\hline \multirow{6}{*}{ Governance } & $\begin{array}{l}\text { National urban } \\
\text { policy framework }\end{array}$ & Local priorities and national policies \\
\hline & $\begin{array}{l}\text { Institutional structure and } \\
\text { processes of local government }\end{array}$ & $\begin{array}{l}\text { Local government structure and } \\
\text { processes; appointment of officials } \\
\text { and governing bodies; corruption; } \\
\text { inter-jurisdictional cooperation }\end{array}$ \\
\hline & $\begin{array}{l}\text { Role of local government in the } \\
\text { context of decentralization }\end{array}$ & $\begin{array}{c}\text { Decentralization impacts on } \\
\text { local government }\end{array}$ \\
\hline & Metropolitan government & Inter-jurisdictional cooperation \\
\hline & Capacity & $\begin{array}{c}\text { Capacity and development priorities; } \\
\text { institutional strengthening and } \\
\text { building priorities; attracting and } \\
\text { retaining talent }\end{array}$ \\
\hline & $\begin{array}{l}\text { Relationship with the private } \\
\text { sector and civil society }\end{array}$ & $\begin{array}{l}\text { Relationship with the private sector; } \\
\text { modes of private sector cooperation; } \\
\text { relationship with civil society; local } \\
\text { government capture }\end{array}$ \\
\hline
\end{tabular}

Source: Cities Alliance, 2006.

\subsection{Developing the Periurban Interface (Urban-Rural Reef)}

The global urbanization processes and the growth in fragmented urban form leads to metropolization, and thus its metapolization model and lifestyle, with overlapping rural and urban areas in polycentric city-regions [29,30]. Although the increase in urbanization and sprawling (low-density expansion) has the benefits of overall economic development, improving the capital accumulation, the infrastructure's network, and the amenities allocation within high-density lands, this process also can hide deep socio-economic inequalities in terms of access to benefits in the low-density urban areas and generated value between interfaces. Furthermore, there are significant negative externalities, like the environmental costs of transportation, work-home commute, $\mathrm{CO}_{2}$ emissions, consumption increasing, and blocked sustainable development efforts [31,32]. As a result, the vulnerability of peri-urban agriculture land uses has been intensified [31,32].

As the urban-rural shared metabolism is critical for the efficient nutrient exchange and for maximizing the functionality of the urban interface as an important metabolic mechanism [29], the peri-urbanization trend has been leading city management pertaining to both of city and farmlands' living, growth, and resilience. In fact, cities are increasingly vulnerable to shocks that cause rapid changes in their external and internal environments. In this crisis context, cities can perform better with mixed land-uses and a synergic development that links rural and urban systems in peri-urban interfaces [29]. Hereupon, peri-urban is known as a new kind of hop-spot, including a multi-functional landscape for urban renewal and development [33]. Consequently, a successful urban performance, rather than maintaining the existing roles of stakeholders, economic structures and institutional status, will need a more adaptive approach within a cooperative and integrative framework.

\subsection{Framework for Urban-Rural Reef Development}

Moving the sprawling city into the peri-urbanization, the paradigm of total landscape development has evolved from the separately strategic urban and rural planning to a mixed-use paradigm toward metropolitan and regional scales. The latest theory of the mixed-use paradigm offers an approach in which urban and agricultural areas are seen as an integrated identity. The form and function in the specific areas of such city-farmlands have been interpreted as determining factors in their metabolism, growth and resilience [6]. 
Drawing from complex topographies of coral reefs, a city reef creates more interfaces between the functions of PUI with high structural complexity, in which vibrant economic growth and resilience are expected in both urban and rural areas. Coral reefs provide more use of niches and greater metabolic exchanges, aggregating nutrient resources within complex nexuses. Similarly, an Urban-Rural Reef, placing over half of the population in less than three present of the total land area, is noted for its significant food production from surrounding metropolitan-area farms on minimal land, mixed poor-rich areas, and desire for concentricity with low-density development at the peri-urban interface (PUI) [13].

Meanwhile, the newly combined rural-urban theory lacks a comprehensive vision of the integrated key components that collectively contribute to building a complex adaptive ecosystem within high-rugosity (a greater degree of structural complexity) regions if the mutual impacts of growth and resilience planning are to be considerable. The description of such Urban-Rural Reef ecosystems provides measures of nutrient complexity that give us insights that help to understand and manage sustainable development [34]. It gathers various integrated key components and their characteristics, which collectively contribute to build a complex adaptive ecosystem that fosters growth, poverty eradication, environmental sustainability, and that considers synergies and trade-offs between sectors joined together in development objectives.

Likewise, urban sprawl in Portugal due to profound changes promoted by democracy, European integration and increased emigration has led to advanced polarization into peripheries, where conflicting priorities for development are inevitable. Therefore, Portugal, on one the hand, despite the strong capability of infrastructural inputs, and greater cohesion and qualification efforts, still has a fragile sustainability in terms of development into many rural-urban systems. On the other hand, it has differentiated their residents in terms of the diverse socioeconomic inequalities in access to the amenities, health, and well-being required for sustainment in their development [30]. To illustrate this, fragile social and environmental conditions are observed in more unequal living places between Lisbon and its peri-urban area and within the metropolitan area of Lisbon itself, or, similarly, Porto.

Considering the high potentiality of urban-rural integration to build growing and resilient systems for both city and form alike [13], urban-rural reefs create an integrative framework for sustainability. Conducting an extensive literature review of previous studies, we derived this ecosystem through three main component groups (Table 2) of urban interface complexity (rugosity), interaction approaches between stakeholders, and effective and infrastructural factors (like supportive governance in reducing disaster risk, comparing a specific amount of $\mathrm{O}_{2}$ in coral reefs).

When determining the high structural complexity of the interface, rugosity is the basis for distinguishing an urban-rural reef where the existence of more use niches and greater metabolic exchange is expected. To ascertain potential high-rugosity regions, different indicators are used, including the urban and agriculture vitality and their variables (AV, UA, and MD indicators in Table 2). Numerous studies investigated the links between urban areas and surrounding farmlands, including interfaces, interlace or buffers, and their role in sustainable development in these areas. Although the existence of rugosity has naturally been admitted in some studies or practices, this possibly is not being explicitly embraced. As an example, Copenhagen's Finger Plan in 1947 was a good example of a transportation solution, rather than an urban-rural solution, which developed the rugosity concept. Other examples include some of United States counties with high-rugosity urban areas and urban growth boundaries, like Lancaster County, Pennsylvania, and Portland [34]. The emergence of expanded concentration in some of the specific metapolized spaces in Portugal has wrought compact spaces (rugosity) alongside some of the city-farm proximities.

In the groundwork study of the initiated rugosity concept [34], an innovative formulation was applied using the Urbanized Area (UA) perimeter as the basis of measuring the rural-urban interface and eventually for calculating the rugosity. In our study, to investigate the urban-rural reef attributes, the primary step has been discovering regions with a greater urban interface length and high rugosity. Estimating an approximate area embedding an urban-rural reef was a sufficiently 
met need to achieve the study objectives and create a comprehensive image of the urban-rural reef. Meanwhile, the calculation of the precise amount of rugosity, the mathematic formulation and examining associations with related indicators of the urban-rural reef in Portugal will be the purpose of future studies.

The Instituto Nacional de Estatística (INE) database regarding the population variation, provided by Portuguese municipalities for 30 years, revealed an increasing difference between coastal and inner areas (even inside these areas themselves). Similarly, analytical data from the mobile communication antenna network admitted a distinctive variety in demographic and social-economic vitality across the urban and suburban territories. These regions, like Braga, Porto, Leiria-Lisboa-Setúbal, and Aveiro, possess specific interfaces that held both low and high densities (Figure 1). The study was applied to the Aveiro-Ílhavo axis as a very specific and interesting dynamics case study, containing a greater interchange across urban and non-urban lands (green arrows) in which some of the determining characteristics in this region were embedded.

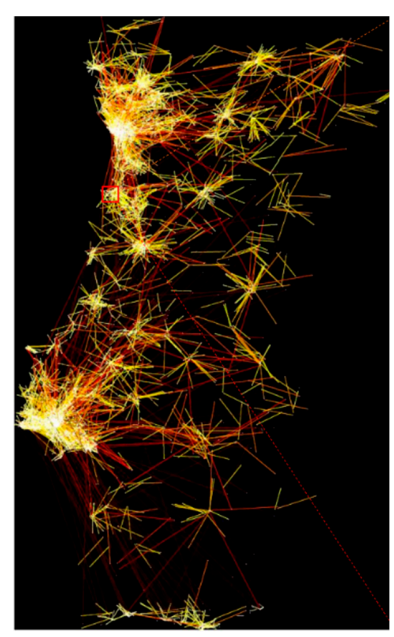

(a)

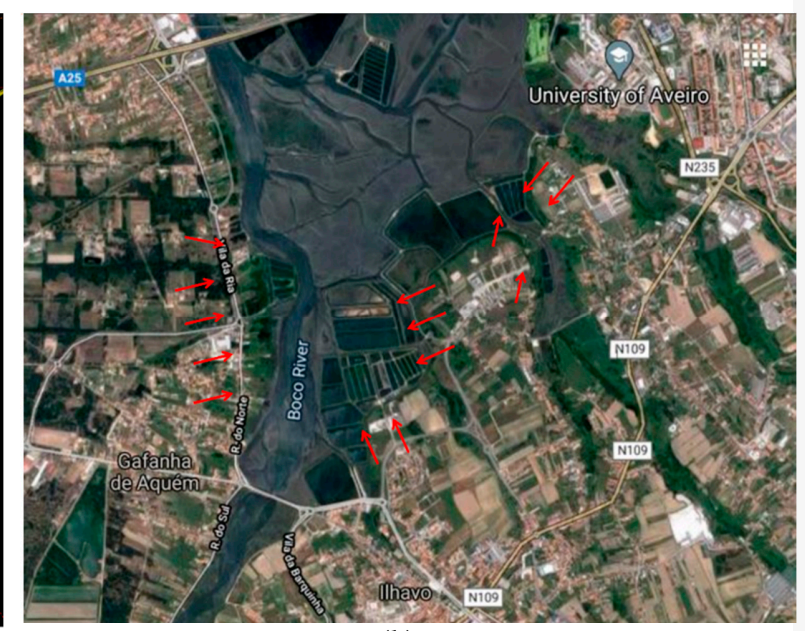

(b)

Figure 1. Commuting distances and the rugosity in Urban Land Uses of Aveiro-Ílhavo axis. (a) A growing contrast between coastal and inner areas has led to a rise in the ultra-peripheral regions of the archipelagos like the Aveiro region; (b) Aveiro region as a region prone to creating an urban-rural ecosystem. Source: Balázs Cs. C.et al., (2013, p. 1470) and Google Earth.

Being under extreme pressure to both develop housing and have an abundant productive farmland, and combining a high natural capital with high levels of poverty accompanied by rapid social, technological, and environmental change are both requirements for selection as a region that embraces urban-rural reef ecosystems [30]. Aveiro has many attractions of big-city life for its inhabitants, with a population of 74,000 in a total area of $199.7 \mathrm{~km}^{2}$, and known as a dynamic medium-sized city. It is the focal point of an industrially developed region, and also a city of commerce and services and a growing center of leisure and culture [35]. 
Table 2. Component groups of the Urban-Rural Reef and their respective indicators.

\begin{tabular}{|c|c|c|c|}
\hline Key Components & Indicator/Measurement & Variables/Parameters & Reference (Some of) \\
\hline \multirow{6}{*}{$\begin{array}{l}\text { The structural complexity of the } \\
\text { urban interface }\end{array}$} & \multirow[b]{3}{*}{ Agricultural Vitality (AV) } & $\begin{array}{l}\text { Agricultural commodity sales and total acres } \\
\text { in active farming (AV1) }\end{array}$ & {$[6]$} \\
\hline & & $\begin{array}{l}\text { Auxiliary deriving incomes (wind } \\
\text { energy (AV2)) }\end{array}$ & {$[6]$} \\
\hline & & $\begin{array}{l}\text { On-farm non-agricultural activities } \\
\text { (Agritourism, energy generation, and } \\
\text { cash-only sales (AV3) }\end{array}$ & {$[36]$} \\
\hline & \multirow[t]{3}{*}{ Urban Vitality (UA) } & $\begin{array}{c}\text { Population gain or population change } \\
\text { (considering its association with migration } \\
\text { patterns, housing development, and related } \\
\text { job market opportunities (UA2)) }\end{array}$ & {$[37,38]$} \\
\hline & & Housing stress (UA3) & \\
\hline & & Land-use density (UA4) & [29] \\
\hline
\end{tabular}


Table 2. Cont

\begin{tabular}{|c|c|c|c|}
\hline Key Components & Indicator/Measurement & Variables/Parameters & Reference (Some of) \\
\hline \multirow{7}{*}{$\begin{array}{c}\text { Infrastructural factors (Technical and } \\
\text { Administrative Infrastructure and } \\
\text { Section) (IF) }\end{array}$} & \multicolumn{2}{|c|}{ Driving government policies (land-use regulations, metabolic flows (IF1)) } & [31] \\
\hline & Natural and cultural vitality (IF2) & Community engagement & [30] \\
\hline & \multirow{2}{*}{ Technological and technical support (IF3) } & Appearance and spread of new technologies & {$[29,40]$} \\
\hline & & Technical infrastructure & [41] \\
\hline & \multirow{2}{*}{ Socio-economic vitality (IF4) } & $\begin{array}{l}\text { Immigrants adapting to lifestyle, job, } \\
\text { and incomes }\end{array}$ & {$[42]$} \\
\hline & & $\begin{array}{l}\text { Externalities (indirect benefit to economic } \\
\text { agents/social benefits) }\end{array}$ & [43] \\
\hline & \multicolumn{2}{|c|}{$\begin{array}{l}\text { Socio-psychological impacts (collection of values, attitudes, and behavior patterns of rural } \\
\text { areas people that are influenced by urbanization) }\end{array}$} & {$[44,45]$} \\
\hline \multirow{3}{*}{$\begin{array}{l}\text { Interaction approaches of components } \\
\text { (IAC) }\end{array}$} & $\begin{array}{l}\text { The mediating role of stakeholders } \\
\text { (IAC1) }\end{array}$ & The mediating role of stakeholders & {$[43,46]$} \\
\hline & $\begin{array}{l}\text { Locally oriented and multifunctional } \\
\text { farming (Civic Agriculture (IAC2)) }\end{array}$ & $\begin{array}{l}\text { Locally oriented and multifunctional farming } \\
\text { (Civic Agriculture) }\end{array}$ & {$[30,41]$} \\
\hline & $\begin{array}{l}\text { Local government/constitutes and locally } \\
\text { adopted management strategies (IAC3) }\end{array}$ & $\begin{array}{c}\text { Purposeful rewilding } \\
\text { Conservation and development of valuable } \\
\text { cultural landscapes }\end{array}$ & {$[47,48]$} \\
\hline
\end{tabular}


The complexity of the Urban-Rural Reef ecosystem, as well as its cross-sectoral links between different components, supports collective actions among engaged stakeholders that create resilient ecosystems. It produces a nutrient environment of exchanging goods and services that might offer diverse interactions between regional farms and their cities to absorb shared metabolisms (IAC factors).

The dynamic of the peri-urban shows constant intensive socio-demographic and socio-cultural changes and different political situations. These transitions are grown in proper technical and administrative infrastructures, including the presence of new technology businesses and rich cultural opportunities, resulting in a high level of economic development (IF factors). More infrastructural factors, more nutrient circumstances and more profitable frameworks are expected in such peri-urban areas. To illustrate, a highly qualified labor force and job-seeking immigrants are both parties attracted to the promising opportunities in these socio-economically developing regions [36].

The mixed and multifunctional identification of peri-urban systems (urban-rural reef ecosystems), implies that the development process is an active fact. Thereby, PDS in a rural-urban reef ecosystem is truly realized by considering the cooperation between participating stakeholders and a wide set of sustainability indicators within uncertain conditions.

Therefore, studying urban-rural reefs helps to understand, plan, and assess the development in these regions, and could affect the quality of sustainable development in the whole ecosystem. Drawing from the CDS and adapting the explored indicators of the urban-rural reefs, our study concludes Table 3 by reaching a more obvious perspective on the related criteria and indicators of development strategies in such ecosystems to provide a basis for evaluating and monitoring peri-urban programs.

\subsection{Periurban Sustainability Evaluation}

According to the UN Habitat Report, a wide range of cities around the world (about 200) has been applied to the City Development Strategy (CDS) as part of a successful strategic plan to catch and capitalize on available opportunities for their cities [49]. Notwithstanding this, CDS has provided a striking package of issues and building blocks for the cities applying these strategies; the major concern is successful implementation. The significance of implementing the development strategies across urban-rural areas increases when multiple stakeholders and functions are engaged in planning strategies.

The Analytic Hierarchy Process (AHP) and the Analytic Network Process (ANP), two traditional Multi-Criteria Decision Making (MCDM) methods, were developed by Tomas Saaty [50-52] to organize and analyze complex decision problems. A matrix of judgments on the relative preference between each pair of alternatives/sub-alternatives is obtained by pairwise comparison $[53,54]$. Finally, the relative importance of each decision criterion is identified. Hence, AHP and questionnaire surveys were applied to weigh each sustainability criterion when estimating the effect of a peri-urban development. In this study, in this study, by translating vision into a couple of levels, including the criteria and their categorized indicators and masseurs' levels, the AHP created an integrated and coordinated look at the performance of development strategies in the peri-urban.

In general, the AHP approach consists of four main components: vision, criteria, index, and metrics, Figure 2. Since the AHP method is not able to perceive internal relations between the elements, ANP was developed to provide comparisons between elements of the same cluster regardless of their hierarchy [55]. 
Table 3. Relevant Criteria and indicators of PDS for evaluating development strategies.

\begin{tabular}{|c|c|c|c|c|c|c|c|}
\hline \multirow{2}{*}{$\begin{array}{c}\text { Criteria } \\
\text { Indicator }\end{array}$} & \multicolumn{4}{|c|}{ Environmental Protection } & \multirow{2}{*}{$\begin{array}{c}\text { Economic Development } \\
\begin{array}{c}\text { Spatial formation of urban/rural facilities } \\
\text { and equipment }\end{array}\end{array}$} & \multicolumn{2}{|c|}{ Social Justice } \\
\hline & & Governance & & Financial resources & & Environmental sustainability & Livelihood and vitality (farm and city) \\
\hline Measurements & 1. & $\begin{array}{l}\text { Participation and involvement } \\
\text { rate of engaged stakeholders in } \\
\text { decision-making in urban plans } \\
\text { Local governance/constitutes } \\
\text { and locally adapted } \\
\text { management strategies } \\
\text { Public sector investment and } \\
\text { participation in PDS } \\
\text { program implementation } \\
\text { Informal engagement in } \\
\text { decision-making processes } \\
\text { and developments }\end{array}$ & $\begin{array}{l}1 . \\
2 . \\
3 . \\
4 . \\
5 .\end{array}$ & $\begin{array}{l}\text { Commercialization programs } \\
\text { Economic productive programs } \\
\text { Strengthen investment areas } \\
\text { Managing Externalities effects } \\
\text { Driving government policies } \\
\text { (in support of agricultural areas } \\
\text { and land use regulations) }\end{array}$ & $\begin{array}{ll}\text { 1. } & \text { Access to energy-efficient resources } \\
\text { 2. } & \begin{array}{l}\text { Distribution of urban facilities } \\
\text { according to the energy } \\
\text { consumption needs }\end{array} \\
\text { 3. } & \begin{array}{l}\text { Locally oriented and } \\
\text { multifunctional farming }\end{array} \\
\text { 4. } & \text { Public transportation performance } \\
\text { 5. } & \begin{array}{l}\text { Appropriate access to urban and } \\
\text { suburban terminals and } \\
\text { transportation routes }\end{array} \\
\text { 6. } & \begin{array}{l}\text { Diversity of site-specific resources } \\
\text { for competing in } \\
\text { peri-urban environments }\end{array}\end{array}$ & $\begin{array}{ll}\text { 1. } & \begin{array}{l}\text { Utilizing } \\
\text { renewable energy }\end{array} \\
\text { 2. } & \begin{array}{l}\text { Quality of } \\
\text { drinking water }\end{array} \\
\text { 3. } & \begin{array}{l}\text { Protection of } \\
\text { environmentally }\end{array} \\
\text { sensitive areas } & \text { Recycling }\end{array}$ & $\begin{array}{l}\text { Livelihood: } \\
\text { 1. Access to adequate housing } \\
\text { 2. } \\
\text { Construction program tailored to } \\
\text { urban needs } \\
\text { 3. Support for } \\
\text { female-headed households } \\
\text { 4. Providing daily urban services } \\
\text { for low-income people } \\
\text { Agriculture Vitality: } \\
\text { 1. A higher value of agricultural } \\
\text { production (agricultural } \\
\text { commodity sales and total acres } \\
\text { in active farming) } \\
\text { 2. Auxiliary deriving incomes and } \\
\begin{array}{l}\text { on-farm } \\
\text { non-agricultural activities }\end{array} \\
\text { Urban Vitality: } \\
\text { 1. Population gain or } \\
\text { 2. Population change } \\
\text { 2. Housing stress } \\
\text { 3. Land-use density }\end{array}$ \\
\hline
\end{tabular}




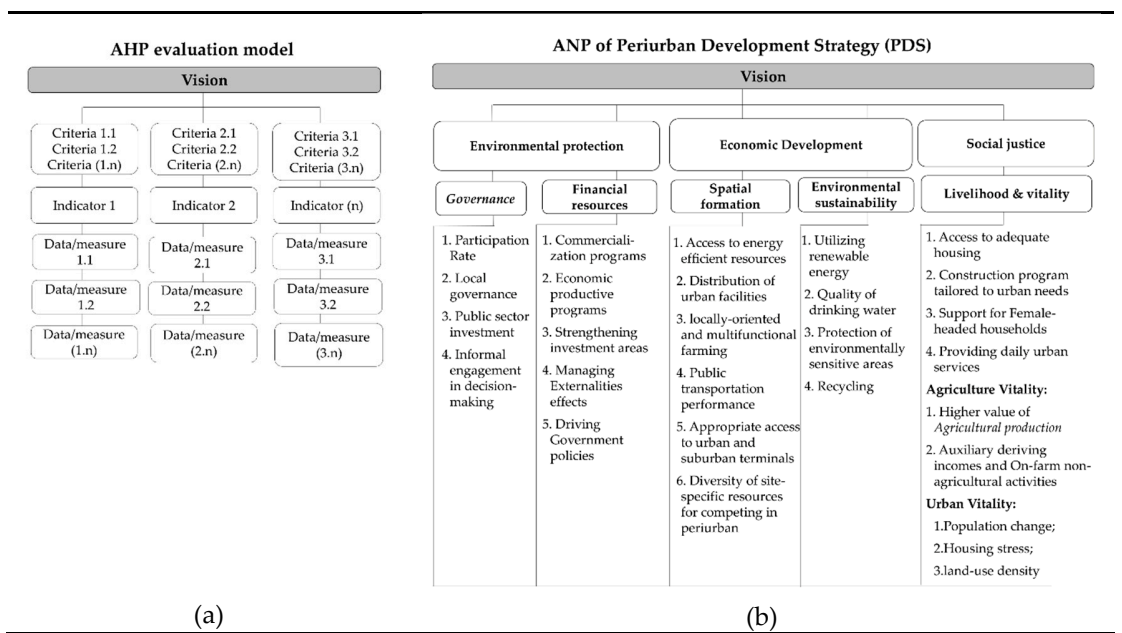

Figure 2. AHP evaluation model with an emphasis on network analysis and ANP of Periurban Development Strategy (PDS). (a) The conceptual model of AHP; (b) Extracted PDS strategies in ANP.

Using a Network Analysis Process (ANP), AHP links the criteria and indicators of objectives of development strategies, quantifies qualitative factors, and consequentially determines the feasibility of each indicator based on numbers and figures. It assists in clarifying which of the indicators of the program is more realizable, and what the rate of realization of indicators is. Due to this, the structural form of ANP for the Periurban Development Strategy (PDS) is demonstrated in Figure 2.

\subsection{AHP Implementation Steps}

Generally, there are five main steps to apply the AHP process. These steps are:

1. Defining the structure of the AHP approach through the internal relationship of each of the perspectives, criteria, indicators, and metrics. Schematic structuring of the ANP network model is pictured, based on the defined relationships in the previous step (see Figure 2);

2. Compiling the weights of the defined criteria, indicators, and metrics that can be obtained using binary comparative matrices. In this study, the relative importance of each option is determined, which will be achieved according to a table-base (Table 4). Definitions of the criteria and indicators' weights are found by performance appraisal teams consisting of experts.

3. Calculating the weight of each metric and providing a comparative matrix for macro goals (components of sustainable development objectives);

4. Determining the scales (measurement) of each measure using the variable suggestions, according to Table 2;

5. Determining the system performance condition for a specific period.

Table 4. Weighing each criterion based on the relative importance.

\begin{tabular}{cc}
\hline Intensity of Importance & Definition \\
\hline Equal importance & 1 \\
\hline Moderate importance & 3 \\
\hline Strong importance & 5 \\
\hline Very strong importance & 7 \\
\hline Extreme importance & 9 \\
\hline
\end{tabular}




\subsection{Quantifying Items}

The primary step in quantifying the exploited criteria is creating the comparative matrix using the components of sustainable development objectives as the macro goals for the criteria. Our study used experts' opinions to make individual evaluations in order to determine the values of the elements of pairwise comparison matrices (Table 5).

Table 5. Comparative matrix of macro goals for sustainable development.

\begin{tabular}{ccccc}
\hline Score & $\begin{array}{c}\text { Development of } \\
\text { Social Justice }\end{array}$ & Economic Development & Environmental Protection & Objectives \\
\hline $\begin{array}{c}\text { Development of } \\
\text { social justice }\end{array}$ & 1 & 6 & 9 & 0.576 \\
\hline Economic development & 1.66 & 1 & 7 & 0.38 \\
\hline Environmental protection & 0.11 & 0.14 & 1 & 0.04 \\
\hline
\end{tabular}

Calculating the primary dependency matrix is acquired in the next step by multiplying matrices of index scores based on criteria in the criteria score matrix. As a result, the final dependency matrix will be gained by multiplying the initial dependence matrix by the score of each measure, following the process in Figure 3.

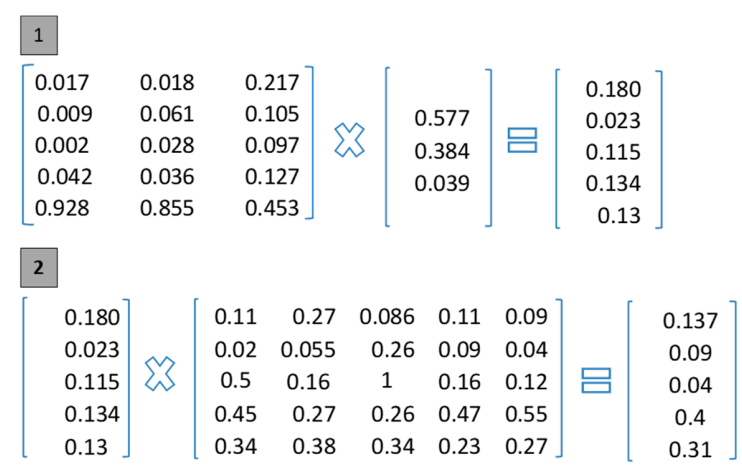

Figure 3. Calculating the primary dependency matrix.

Using dependency weights (including detailed indicators) and weighing the measures, the final scores (weights) of each indicator are accountable. In other words, the total weighting of measurements can be obtained by multiplying the weight of each measure by the weight of the related dependency matrix in the score of the respective measurement (see Tables 6-10).

Table 6. Calculating the total weight of the governance index based on metrics.

\begin{tabular}{cclcc}
\hline Indicator & Dependency Matrix Value & \multicolumn{1}{c}{ Measurements } & Weight & Total Weight \\
\hline \multirow{3}{*}{ Governance } & \multirow{3}{*}{0.137} & 1. Participation rate & 0.135 & 0.0186 \\
\cline { 3 - 5 } & & 2. Local governance & 0.186 & 0.017 \\
\cline { 3 - 5 } & & $\begin{array}{l}\text { 3. Public sector investment } \\
\text { 4. Informal engagement } \\
\text { in decision-making }\end{array}$ & 0.40 & 0.017 \\
\hline
\end{tabular}


Table 7. Total weight of the financial resources index based on metrics.

\begin{tabular}{cclcc}
\hline Indicator & Dependency Matrix Value & \multicolumn{1}{c}{ Measurements } & Weight & Total Weight \\
\hline \multirow{3}{*}{ Finance resource } & \multirow{3}{*}{0.09} & 1. Commercialization programs & 0.24 & 0.022 \\
\cline { 3 - 5 } & & 2. Economic productive programs & 0.019 & 0.001 \\
\cline { 3 - 5 } & & 3. Strengthening investment areas & 0.15 & 0.015 \\
\cline { 3 - 5 } & & 4. Managing externalities' effects & 0.26 & 0.025 \\
\cline { 3 - 5 } & & 5. Driving government policies & 0.316 & 0.029 \\
\hline
\end{tabular}

Table 8. Total weight of the spatial formation of urban/rural facilities and equipment index based on metrics.

\begin{tabular}{|c|c|c|c|c|}
\hline Indicator & Dependency Matrix Value & Measurements & Weight & Total Weight \\
\hline \multirow{6}{*}{ Spatial formation } & \multirow{6}{*}{0.044} & 1. Access to energy-efficient resources & 0.263 & 0.011 \\
\hline & & 2. Distribution of urban facilities & 0.128 & 0.005 \\
\hline & & $\begin{array}{l}\text { 3. Locally oriented and } \\
\text { multifunctional farming }\end{array}$ & 0.20 & 0.008 \\
\hline & & 4. Public transportation performance & 0.15 & 0.006 \\
\hline & & $\begin{array}{l}\text { 5. Appropriate access to urban and } \\
\text { suburban terminals }\end{array}$ & 0.18 & 0.008 \\
\hline & & $\begin{array}{l}\text { 6. Diversity of site-specific resources } \\
\text { for competing in } \\
\text { peri-urban environments }\end{array}$ & 0.07 & 0.003 \\
\hline
\end{tabular}

Table 9. Total weight of the environmental sustainability index based on metrics.

\begin{tabular}{|c|c|c|c|c|}
\hline Indicator & Dependency Matrix Value & Measurements & Weight & Total Weight \\
\hline \multirow{4}{*}{ Environmental sustainability } & \multirow{4}{*}{0.4} & 1. Utilizing renewable energy & 0.04 & 0.01 \\
\hline & & 2. Quality of drinking water & 0.14 & 0.05 \\
\hline & & $\begin{array}{l}\text { 3. Protection of environmentally } \\
\text { sensitive areas }\end{array}$ & 0.54 & 0.23 \\
\hline & & 4. Recycling & 0.25 & 0.10 \\
\hline
\end{tabular}

Table 10. Total weight of the livelihood and vitality index based on metrics.

\begin{tabular}{|c|c|c|c|c|c|c|}
\hline Indicator & Dependency Matrix Value & \multicolumn{3}{|c|}{ Measurements } & Weight & Total Weight \\
\hline \multirow{11}{*}{ Livelihood and Vitality } & \multirow{11}{*}{0.31} & \multicolumn{3}{|c|}{ 1. Access to adequate housing } & 0.027 & 0.008 \\
\hline & & \multirow{3}{*}{ Livelihood } & 2. Construction progr & n tailored to urban needs & 0.032 & 0.01 \\
\hline & & & 3. Support for female & aded households & 0.076 & 0.02 \\
\hline & & & 4. Providing daily url & services & 0.032 & 0.01 \\
\hline & & \multirow{7}{*}{ Vitality } & \multirow{4}{*}{ Agriculture Vitality } & $\begin{array}{l}\text { 1. Higher value of } \\
\text { Agricultural production }\end{array}$ & 0.046 & 0.015 \\
\hline & & & & 2. Auxiliary deriving & & \\
\hline & & & & incomes and on-farm & 0.37 & 0.11 \\
\hline & & & & non-agricultural activities & & \\
\hline & & & \multirow{3}{*}{ Urban Vitality } & 1. Population change & 0.035 & 0.01 \\
\hline & & & & 2. Housing stress & 0.31 & 0.1 \\
\hline & & & & 3. Land-use density & 0.06 & 0.02 \\
\hline
\end{tabular}

\section{Results (Evaluating the System Performance)}

In the final step, the ultimate summations of the evaluated indicators assist in classifying the level of their performance. The higher the value of the indicator performance, the greater the expected feasibility (Table 11). 
Table 11. The final score of each performance indicator.

\begin{tabular}{|c|c|c|c|}
\hline Indicators & Measurements & Score & Final Score $\left({ }^{*} 100\right)$ \\
\hline \multirow{5}{*}{ Governance } & $\begin{array}{l}\text { Participation and involvement rate of } \\
\text { engaged stakeholders in } \\
\text { decision-making in urban plans }\end{array}$ & 0.0186 & \\
\hline & $\begin{array}{l}\text { Local governance/constitutes and locally } \\
\text { adapted management strategies }\end{array}$ & 0.017 & \\
\hline & $\begin{array}{l}\text { Public sector investment and } \\
\text { participation in PDS } \\
\text { program implementation }\end{array}$ & 0.017 & \\
\hline & $\begin{array}{l}\text { Informal engagement in } \\
\text { decision-making processes } \\
\text { and developments }\end{array}$ & 0.037 & \\
\hline & & & 8.96 \\
\hline \multirow{6}{*}{ Finance resource } & Commercialization programs & 0.022 & \\
\hline & Economic productive programs & 0.001 & \\
\hline & Strengthen investment areas & 0.015 & \\
\hline & Managing externalities effects & 0.025 & \\
\hline & $\begin{array}{l}\text { Driving government policies (financial } \\
\text { sides in Support for agricultural areas } \\
\text { and land use regulations) }\end{array}$ & 0.029 & \\
\hline & & & 9.2 \\
\hline \multirow{6}{*}{$\begin{array}{l}\text { Spatial formation of } \\
\text { urban/rural facilities } \\
\text { and equipment }\end{array}$} & Access to energy-efficient resources & 0.011 & \\
\hline & $\begin{array}{l}\text { Distribution of urban facilities according } \\
\text { to energy consumption needs }\end{array}$ & 0.005 & \\
\hline & $\begin{array}{l}\text { Locally oriented and } \\
\text { multifunctional farming }\end{array}$ & 0.008 & \\
\hline & Public transportation performance & 0.006 & \\
\hline & $\begin{array}{l}\text { Appropriate access to urban and } \\
\text { suburban terminals and } \\
\text { transportation routes }\end{array}$ & 0.008 & \\
\hline & $\begin{array}{l}\text { Diversity of site-specific resources for } \\
\text { competing in peri-urban environments }\end{array}$ & 0.003 & \\
\hline
\end{tabular}


Table 11. Cont.

\begin{tabular}{|c|c|c|c|c|}
\hline Indicators & \multicolumn{2}{|c|}{ Measurements } & Score & Final Score $(* 100)$ \\
\hline \multirow{5}{*}{ Environmental sustainability } & \multicolumn{2}{|c|}{ Utilizing renewable energy } & 0.01 & \\
\hline & \multicolumn{2}{|c|}{ Quality of drinking water } & 0.05 & \\
\hline & \multicolumn{2}{|c|}{ Protection of environmentally sensitive areas } & 0.23 & \\
\hline & \multicolumn{2}{|l|}{ Recycling } & 0.10 & \\
\hline & & & & 39.6 \\
\hline \multirow{10}{*}{$\begin{array}{c}\text { Livelihood } \\
\text { and } \\
\text { Vitality }\end{array}$} & \multirow{4}{*}{ Livelihood } & $\begin{array}{l}\text { Access to } \\
\text { adequate housing }\end{array}$ & 0.008 & \\
\hline & & $\begin{array}{l}\text { Construction program } \\
\text { tailored to urban needs }\end{array}$ & 0.01 & \\
\hline & & $\begin{array}{l}\text { Support for } \\
\text { female-headed households }\end{array}$ & 0.02 & \\
\hline & & $\begin{array}{l}\text { Providing daily urban } \\
\text { services for } \\
\text { low-income people }\end{array}$ & 0.01 & \\
\hline & \multirow[t]{2}{*}{ Agriculture Vitality } & $\begin{array}{l}\text { A higher value of } \\
\text { agricultural production } \\
\text { (agricultural commodity } \\
\text { sales and total acres of } \\
\text { active farming) }\end{array}$ & 0.015 & \\
\hline & & $\begin{array}{l}\text { Auxiliary deriving } \\
\text { incomes and on-farm } \\
\text { non-agricultural activities }\end{array}$ & 0.11 & \\
\hline & \multirow{3}{*}{ Urban Vitality } & $\begin{array}{l}\text { Population gain or } \\
\text { population change }\end{array}$ & 0.01 & \\
\hline & & Housing stress & 0.1 & \\
\hline & & Land-use density & 0.008 & \\
\hline & & & & 29.1 \\
\hline
\end{tabular}

\section{Discussion}

As was demonstrated in the final results of evaluated performance in Table 11, not surprisingly, sustainable development, livelihood and vitality are some of the most effective indicators related to the development of city-farm regions, and peri-urban ecosystems, named urban-rural reefs, in Aveiro, with scores of respectively, 39.6 and 29.1 (see Table 11).

The protection of environmentally sensitive areas, as the most valued measurement in the environmental sustainability indicator, gained the highest score, 23 percent, in comparison to all the remaining indicators. Regarding this assessment, the considerable challenge that the Aveiro region faces in its government and administration of the territory is strengthening the regional and metropolitan dynamics. As noted in the Environmental Implementation Review (EIR) report in Portugal in 2017, one of the main challenges identified concerning the implementation of the EU environmental policy and law in Portugal was enhancing the effective protection of the Natura 2000 network [56]. Hence, in May of 2018, the Portuguese Government adopted the national strategy for nature conservation and biodiversity, which aimed to ensure citizens' health and quality of life in the inner land and make cities more sustainable.

Moreover, in the surrounding city's lands (including forest and farms) the majority of the dedicated budget, approximately $40 \%$ for the Rural Development Program (RDP) of Portugal mainland, involving the Aveiro region, was allocated to environmental priorities. Although this embarked budget is insufficient for most of the relevant challenges in peripheries, emphasizing effective strategies to urban planners can help achieve good environmental status in these regions. To illustrate this, more recent strategies can be mentioned, like restoring forests (especially after the great fires of 2016 and 2017) by replanting with native species or using the association of volunteer firelights, 
enabling multi-functionality in farms near urban areas to supply a diverse range of goods and services to nearby markets, as well as shifting towards organic farming, which provides a progressive trend towards a more sustainable model of farming. On the negative side, despite many attempts to maintain a conservation status for protected species and habitats due to a lack of allocated finances and non-targeted/ambitious objectives in environmental protection plans, the problems of invasive species are still a concern $[30,56]$.

Orientating farm-city cohesion into these strategies and practices causes an intensifying synergy across inter-sectional interactions between engaged actors in such an ecosystem as the rural-urban reef. Therefore, rehabilitation strategies and plans could be extended in promoting urban retention/regeneration of peri-urban ecosystems and rural-urban reefs even with a lower budget, with higher ambitions for the participation of stakeholders.

Recycling and the quality of drinking water were the second- and third-valued scores of the environmental sustainability indicator, with 10 percent and 5 percent. Improving waste management and related marine water strategies, as well as water management, including protection of the quantitative status of groundwater, improving water governance and the need to close gaps in water investment, especially regarding wastewater, is further mainstreamed into urban planning in Portugal to create more sustainable development. In the Aveiro peri-urban, pollution in territorial water resources like Rio Caima, or the problem of managing COVID-19 waste in the pandemic situation [57] that affects public health, cause related struggles for local governments, urban planners, and both urban and peri-urban inhabitants. Besides this, a shortage of groundwater-quality-monitoring networks has restricted the detection of land contaminated by pesticides from agricultural activities or heavy metals from the industry. To illustrate this, some investigations indicate that exposure to nitrate pollution occurs in Aveiro [58]. Considering the high potentiality of integrated urban-rural regions, the quality of the ecosystem sustainability will increase by providing a mutual framework for adapting changes, with interaction between stakeholders [59]. The results of establishing such a framework in terms of the achievements of an urban-rural reef ecosystem performance, like creating an association of cities and regions for sustainable resource management, could be released in future studies.

Regarding livelihood and vitality (of agriculture and urban areas), the highest valued score between measurements, with 11 percent, is auxiliary deriving incomes and on-farm, non-agricultural activities. Contemporary debates on sustainable land use and urban development have (re-)entered significance in agriculture in the urban context through the contextualizing of urban agriculture and peri-urban agriculture (UPUA) concerning societal and economic transformations, EU strategic objectives, policies, and the regional food system approach [60].

The Aveiro region and its high-density peri-urban areas have provided nutrient regions of shared metabolism in agricultural and urban areas; suburban farms produce more value with less land than the national average. These specific ecosystems lay the foundation for a more vigorous approach to sustainability through empowering the vitality of agriculture lands, not only by utilizing the higher value of agricultural production but by using the potentialities of auxiliary-derived incomes, on-farm non-agricultural activities like farm tours [61], and wind farms and solar power plants on agricultural lands [62]. This would have diverse social and economic effects on nearby cities, like the return of financial investments in agricultural activities or creation of more job opportunities.

The housing stress (sub)-measurement was the second determining factor within the urban vitality indicator, with 10 percent of a total of 29.1 scores. The increasing rate of housing compactness in the Aveiro peri-urban has intensified the vitality of city land surrounded by vigorous farmlands, where vitality is defined as the total of energy resources, human existence and activities, and essential elements for achieving urban quality of life [63]. This is due to the growing population, particularly a dramatic increase of $10 \%$ between 1991 and 2001, and a continuous increase in the past 20 years of around 74,000 people, in which the Aveiro municipality has witnessed an exceptional economic growth across small- and medium-sized urban areas (SMUAs) in Portugal, which is more evident in the interfaces of city-farms [35]. 
However, this evolving rate has faced urban areas and land occupation, with indirect or direct side-effects like significant negative externalities and greenhouse gas (GHG) emissions due to increased consumption and home-work commutes [30]. Therefore, peri-urban development strategies (PDS) ought to provide a privileged instrument and framework around which the requirements for meeting the needs of habitants' lives, named livelihoods, could be set up, and simultaneously put up an urban-rural reef for a more vital and sustained ecosystem.

One of the challenges of Portugal in meeting the development objectives is an adequate level of finance for well-implemented policies-especially in the cross-lands of city-farm, such as waste management and support of green activities [56]. Meanwhile, promising strategies for the development of small and medium-sized urban areas (SMUAs), like Aveiro, are benefiting the city and its territory by reinforcing the social and economic balance of Europe at the regional level, the budgets for EU policies also need to be increased [35]. As could be expected, the driving government policies in support of agricultural areas and land use regulations had the highest value of all scores in the finance indicator measurements.

However, the initiative strategies and debates on allocating the budgets of programs that empower urban and peri-urban vigor, sustainability and development are taking place in a more integrated way in an urban-rural reef ecosystem. Aveiro is known as the "City of Innovation" for its projects in the area of the information society and its university. Defining different strategic axes, offering financial support to SMEs, business incubation, and fostering an entrepreneurial culture led to the success of Aveiro [35] in its commercializing programs (in both urban and agricultural services and production) toward the parallel development of the city and its surrounding territory, like the commercialization of urban housing or lands [58]. However, on the negative side, this may imply that the land regularization process and the imposition of certain fees resulted in further marginalizing and causing the migration of poorer people, which profoundly impacts their livelihoods [64].

Citizen participation has been noted as a prerequisite of urban and rural development, upon which lay the foundation for sustainable development. Considering the various interlinkages between stakeholders in the urban-rural reef ecosystem, engaging inhabitants in urban planning will synergistically influence the decision-making of the local government by providing valuable information on the state of well-being, as well as implementing development or resilient programs. Informal engagement in the decision-making processes and developments (the highest score in the governance indicator), and the democratization of planning are used as supplemental forces, beside public participation, to enhance consultative and participative processes in peri-urban planning. Establishing relevant associations like "association of cities and regions" to deter and manage mixed wastes in conjunction with the urban waste, as mentioned in the pandemic, in Aveiro and its attached peripheries helps the local government in planning for sustainable resource management [57]. Furthermore, informal planning transactions, as shown in the experts' opinions, are emphasized as a highly valued requirements, alongside formal participation, wherever actual peri-urban practices suffer from a lack of recognition by formal institutions. To illustrate, relationships between water management in the peri-urban interface and urban food systems regarding recognizing the risks and opportunities related to wastewater use in peri-urban farming have costs for the people living there, as well as in urban and rural areas, similar to the problem of the Caima River [59]. Besides a couple of mentioned measurements regarding the governance indicator, amplifying both the public sector investments and locally adapted management strategies (valued as equated factors with 1.7 percent), will equip the local government with the needed legal and technical skills to enable them to fulfill their mandates and undertake policies of peri-urban development.

The spatial formation of urban/rural facilities and equipment, despite being categorized as the least valued indicator, with 4.1 percent, is among the determining indicators in the performance of the development of peri-urban strategies, and is considered as one of the structural factors. In the spatial formation planning and facility design of urban and rural areas, accessibility was evaluated from various perspectives, including consumer needs (like energy resources or agricultural products), 
variety of activities or strategic locations and, finally, diversity of site-specific resources for competing. According to expert opinion, the importance of "diversity of site-specific resources for competing" and "diversity of site-specific resources for competing" was equally valued, while "access to energy-efficient resources" still has a higher significance for the peri-urban involved city and surrounding area, with high rugosity to equip its habitant and activities. Although some studies demonstrated that the adoption of energy efficiency in rural areas can be significant and differ from that seen in more densely populated areas, access to energy-efficient resources in both regions has remained critical. The role of urban-rural reefs on the efficiency of energy resources and the economic effects of the return to scale should be further assessed by the study.

\section{Conclusions}

In recent decades, an extensive and fragmented process of urbanization has emerged, with dense and compact spaces overlapping with suburban areas to maximize value generation through rural-urban collaboration [40]. This nexus between urban-rural regions through greater urban interface exposure, named "high rugosity", has been associated with the sustained vigor of both urban and agricultural land-uses [13]. In fact, the higher rugosity is provided by the peri-urban; more benefits are expected from the good mobility conditions, flowing materials, and higher urban metabolism.

These regional and metropolitan dynamics in the peri-urban have led various regions of Portugal to feel pressure to enforce them, leading to a specific ecosystem of urban-rural reef. Aveiro, as an exemplary city, has expanded its concentration toward its surrounding lands with an increased nutrient amenities system, the Aveiro reef ecosystem, that has been prone to galvanizing rapid urbanization as a source of socio-economic vitality and poverty reduction. As consequence, creating regions with linked regions of high and low density between the city-farm has possessed Aveiro County, a high-rugosity urban expansion containing a greater interchange across urban and non-urban lands. These areas' spatial, economic and social characteristics have significant effects on both urban and rural development and the need for appropriate urban planning.

Overall, this paper has developed an integrated framework for evaluating the performance of urban-rural reef ecosystems concerning the development strategies which contribute to managing and optimizing their performance. For this purpose, conducting an in-depth study, we extracted a set of listed performance indicators for each sustainability criterion (environmental protection, economic development, and social justice) and related measures, tied to the objectives of development strategies from CDS, and then used them for PDS in the detected Aveiro urban-rural region.

In terms of the development strategies of specific systems of peri-urban interfaces (the urban-rural reef ecosystem), several factors, such as governance, sustainable development and spatial formation of urban-rural facilities, and equipment, livelihood and vitality, were addressed as indicators of the three pillars of sustainable development. The method used was based on three criteria, classified by five indicators and 28 sub-indicators that represent a large number of variables characteristic of the urban-rural contexts studied. Using the Analytic Hierarchy Process (AHP) Approach, our study calculates the effects of the different indicators of each sustainability criterion and related measures on peri-urban development, and assesses the feasibility of each indicator to achieve sustainable urban development.

Author Contributions: This work has Conceptualized urban-rural reef ecosystem and peri-urban development strategy (PDS), using the Multi-Criteria Decision Analysis (MCDM) method and applying the Analytic Hierarchy Process (AHP) approach; Expert Choice software; the Aveiro university online library and other online resources. The data curation, writing-original draft preparation and visualization was done by S.A.; writing-review and editing by C.G.; supervision and project administration by J.M. All authors have read and agreed to the published version of the manuscript.

Funding: This work was financially supported by the research unit on Governance, Competitiveness and Public Policy (UIDB/04058/2020), funded by national funds through FCT-Fundação para a Ciência e a Tecnologia. This research received no external funding. 
Acknowledgments: I would like to thank my supervisors João Matias and Carlos Gonçalves for providing guidance and feedback throughout this work.

Conflicts of Interest: The authors declare no conflict of interest. The funders had no role in the design of the study; in the collection, analyses, or interpretation of data; in the writing of the manuscript, or in the decision to publish the results.

\section{References}

1. A City that Plans: Reinventing urban Planning. Available online: https://doi.org/10.18356/4a540597-en (accessed on 9 July 2016).

2. Monstadt, J.; Meilinger, V. Governing Suburbia through regionalized land-use planning? Experiences from the Greater Frankfurt region. Land Use Policy 2020, 91, 104300. [CrossRef]

3. Ma, W.; Jiang, G.; Chen, Y.; Qu, Y.; Zhou, T.; Li, W. How feasible is regional integration for reconciling land use conflicts across the urban-rural interface? Evidence from Beijing-Tianjin-Hebei metropolitan region in China. Land Use Policy 2020, 92, 104433. [CrossRef]

4. De Silva, M.; Howells, J.; Meyer, M. Innovation intermediaries and collaboration: Knowledge-based practices and internal value creation. Res. Policy 2018, 47, 70-87. [CrossRef]

5. Nations Food and Agriculture Organization of the United. Food and Agriculture Organization of the United Nations. Int. Organ. 1947, 1, 350-353. [CrossRef]

6. Brinkley, C. Cities as Coral Reefs: Using Rugosity to Measure Metabolism across the Urban Interface. Ann. Am. Assoc. Geogr. 2019, 4452, 1541-1559. [CrossRef]

7. Gardner, J.S.; Dekens, J. Mountain hazards and the resilience of social-ecological systems: Lessons learned in India and Canada. Nat. Hazards 2007, 41, 317-336. [CrossRef]

8. Gebre, T.; Gebremedhin, B. The mutual benefits of promoting rural-urban interdependence through linked ecosystem services. Glob. Ecol. Conserv. 2019, 20, e00707. [CrossRef]

9. Jablonski, B.; Carolan, M.; Hale, J.; Thilmany, D.; Love, E.; Christensen, L.O.; Covey, T.; Bellows, L.L.; Cleary, R.; David, O.; et al. Connecting Urban Food Plans to the Countryside: Leveraging Denver's Food Vision to Explore Meaningful Rural-Urban Linkages. Sustainability 2019, 11, 2022. [CrossRef]

10. Kapfudzaruwa, F.; Kudo, S.; Matsuyama, K.; Allasiw, D.I. Rural-Urban Linkages and Sustainable Development: Case Studies from Africa. 2020. Available online: https://books.google.pt/books?hl= en\&lr=\&id=4sXjDwAAQBAJ\&oi=fnd\&pg=PR11\&dq=rural+and +urban +linkages\&ots=EQ34yy1kHL\& sig=1RYPfhMcNtbEJ5yiFjwtpoB_ZDk\&redir_esc=y\#v=onepage\&q=ruralandurbanlinkages\&f=false (accessed on 7 December 2020).

11. Available online: https://www.emerald.com/insight/content/doi/10.1108/eb055234/full/html (accessed on 1 April 2020).

12. UN-Habitat. 2016. Available online: https://www.habitat3.org/the-new-urban-agenda (accessed on 1 April 2020).

13. Brinkley, C. Fringe Benefits: Adding Rugosity to the Urban Interface in Theory and Practice. J. Plan. Lit. 2018, 33, 143-154. [CrossRef]

14. De Graaf, R.S.; Dewulf, G.P.M.R. Applying the lessons of strategic urban planning learned in the developing world to the Netherlands: A case study of three industrial area development projects. Habitat Int. 2010, 34, 471-477. [CrossRef]

15. Econ analysis and Centre for Local Government. The Impacts of City Development Strategies; University of Technology: Sydney, Australia, 2005.

16. Whitmee, S.; Haines, A.; Beyrer, C.; Boltz, F.; Capon, A.G.; Dias, B.F.D.S.; Ezeh, A.; Frumkin, H.; Gong, P.; Head, P.; et al. Safeguarding human health in the Anthropocene epoch: Report of The Rockefeller Foundation-Lancet Commission on planetary health. Lancet 2015, 386, 1973-2028. [CrossRef]

17. Baccini, P.; Brunner, P.H. Metabolism of the Anthroposphere; Springer: Berlin/Heidelberg, Germany, 2012.

18. De Noronha Vaz, E.; Nijkamp, P.; Painho, M.; Caetano, M. A multi-scenario forecast of urban change: A study on urban growth in the Algarve. Landsc. Urban Plan. 2012, 104, 201-211. [CrossRef]

19. Koch, J.; Wimmer, F.; Schaldach, R. Analyzing the relationship between urbanization, food supply and demand, and irrigation requirements in Jordan. Sci. Total. Environ. 2018, 636, 1500-1509. [CrossRef] [PubMed] 
20. United Nations Industrial Development Organization. Integrated Planning \& Sustainable Development: Challenges and Opportunities Synthesis Report; United Nations Industrial Development Organization: Vienna, Austria, 2016.

21. Blackwell, W. Cities of Tomorrow. Available online: https://1lib.eu/book/2455911/81b95c (accessed on 1 June 2014).

22. Atkins, P.J. The charmed circle: Von Thunen and agriculture around nineteenth century London (teaching material). Geography 1987, 72, 129-139.

23. Berke, P.R. Does Sustainable Development Offer a New Direction for Planning? Challenges for the Twenty-First Century. J. Plan. Lit. 2002, 17, 21-36. [CrossRef]

24. Zhang, J.; Rao, Y.; Geng, Y.; Fu, M.; Prishchepov, A.V. A novel understanding of land use characteristics caused by mining activities: A case study of Wu'an, China. Ecol. Eng. 2017, 99, 54-69. [CrossRef]

25. Zeković, S.; Vujošević, M.; Bolay, J.C.; Cvetinović, M.; Miljković, J. Ž.; Maričić, T. Planning and land policy tools for limiting urban sprawl: The example of Belgrade. Spatium 2015, 1, 69-75. [CrossRef]

26. Pelorosso, R. Modeling and urban planning: A systematic review of performance-based approaches. Sustain. Cities Soc. 2020, 52, 101867. [CrossRef]

27. The View from Kiberia Slum City Development Strategy Guidelines: Driving Urban Performance. Available online: https://araburban.org/files/file/cds-gudelines-final-march06.pdf (accessed on 7 December 2020).

28. Rasoolimanesh, S.M.; Badarulzaman, N.; Jaafar, M. City development strategy: Theoretical background, themes, and building blocks. Int. J. Urban Sci. 2016, 20, 285-297. [CrossRef]

29. Brinkley, C. High rugosity cities: The geographic, economic and regulatory pathology of America's most non-concentric urban areas. Land Use Policy 2018, 73, 215-224. [CrossRef]

30. Fernandes, J.A.R.; Seixas, J. Cities and urbanisation in democratic Portugal. Méditerranée 2018. [CrossRef]

31. Martine, G.; McGranahan, G.; Montgomery, M.; Fernández-Castilla, R. The New Global Frontier: Urbanization, Poverty and Environment in the 21st Century; Earthscan: London, UK, 2012.

32. Łaszkiewicz, E.; Łaszkiewicz, E.; Kronenberg, J. Is urban sprawl linked to green space availability? Ecol. Indic. 2020, 108, 105723. [CrossRef]

33. Nilsson, K.; Nielsen, T.S.; Aalbers, C.; Bell, S.; Boitier, B.; Chery, J.P.; Fertner, C.; Groschowski, M.; Haase, D.; Loibl, W.; et al. Strategies for sustainable urban development and urban-rural linkages. Eur. J. Spat. Dev. 2014. Available online: http://www.nordregio.se/EJSD/ (accessed on 7 December 2020).

34. Brinkley, C. Fringe Benefits. Pers. Rev. 2013, 2, 88-90. [CrossRef]

35. Challenges of Small and Medium-Sized Urban Areas (SMUAs), their Economic Growth Potential and Impact on Territorial Development in the European Union and Latvia. Available online: https://www. eukn.eu/fileadmin/Files/Presidencies/2015_Latvia/LatvianPresidency-2015_Final_Report_.pdf (accessed on 25 May 2015).

36. Mahendru, M. Financial well-being for a sustainable society: A road less travelled. Qual. Res. Organ. Manag. Int. J. 2020. [CrossRef]

37. Ravenscroft, N. The Vitality and Viability of Town Centres. Urban Stud. 2000, 37, 2533-2549. [CrossRef]

38. Arrow, K.; Bolin, B.; Costanza, R.; Dasgupta, P.; Folke, C.; Holling, C.S.; Jansson, B.O.; Levin, S.; Mäler, K.G.; Perrings, C.; et al. Economic growth, carrying capacity, and the environment. Environ. Dev. Econ. 1996, 1, 104-110. [CrossRef]

39. Wheeler, S.M. The Evolution of Built Landscapes in Metropolitan Regions. J. Plan. Educ. Res. 2008, 27, 400-416. [CrossRef]

40. Shaw, B.J.; Van Vliet, J.; Verburg, P. The peri-urbanization of Europe: A systematic review of a multifaceted process. Landsc. Urban Plan. 2020, 196, 103733. [CrossRef]

41. Francis, C. Awakening Community Intelligence_ CSA Farms as 21st Century Cornerstones. NACTA J. 2016. Available online: https://books.apple.com/us/book/awakening-community-intelligence/id 992577430 (accessed on 24 January 2020).

42. Fang, C.; Yu, D. Urban agglomeration: An evolving concept of an emerging phenomenon. Landsc. Urban Plan. 2017, 162, 126-136. [CrossRef]

43. Broitman, D.; Griskin, V.; Czamanski, D. Unbundling negative and positive externalities of nature in cities: The influence of wild animals on housing prices. Urban Stud. 2018, 56, 2820-2836. [CrossRef] 
44. Defining the Peri-Urban: Rural-Urban Linkages and Institutional Connections | Définir les zones Périurbaines: Liens avec les Milieux Ruraux et Urbains et Cadres Institutionnels. Available online: http://www.fao.org/ tempref/docrep/fao/003/X8050t/X8050T03.pdf (accessed on 24 January 2020).

45. Biegańska, J.; Środa-Murawska, S.; Kruzmetra, Z.; Swiaczny, F. Peri-Urban Development as a Significant Rural Development Trend. Quaest. Geogr. 2018, 37, 125-140. [CrossRef]

46. Spaliviero, M.; Pelling, M.; Lopes, L.F.; Tomaselli, C.; Rochell, K.; Guambe, M. Resilience planning under information scarcity in fast growing African cities and towns: The CityRAP approach. Int. J. Disaster Risk Reduct. 2020, 44, 101419. [CrossRef]

47. Plieninger, T.; Draux, H.; Fagerholm, N.; Bieling, C.; Bürgi, M.; Kizos, T.; Kuemmerle, T.; Primdahl, J.; Verburg, P.H. The driving forces of landscape change in Europe: A systematic review of the evidence. Land Use Policy 2016, 57, 204-214. [CrossRef]

48. Rocha, S.M.; Zulian, G.; Maes, J.; Thijssen, M. Mapping and assessment of urban ecosystems and their services. Jt. Res. Cent. 2015. Available online: https://core.ac.uk/reader/38631950 (accessed on 1 July 2020).

49. Un-Habitat. Planning and Design for Sustainable Urban Mobility; Routledge: Abingdon, UK, 2013.

50. Saaty, T.L. The Analytic Hierarchy Process: Planning, Priority Setting, Resource Allocation. Eur. J. Oper. Res. 1982. Available online: https://books.google.pt/books?id=lfDXAAAAMAAJ\&q= bibliogroup:\%22Multicriteria+decision+making\%22\&dq=bibliogroup:\%22Multicriteria+decision+ making\%22\&hl=en\&sa=X\&ved=2ahUKEwiPx-GOoq3sAhVFhRoKHagcDkIQ6AEwAHoECAEQAg (accessed on 11 October 2020).

51. Saaty, T.L. What is the Analytic Hierarchy Process? In Mathematical Models for Decision Support; Springer: Berlin/Heidelberg, Germany, 1988; pp. 109-121.

52. Saaty, T.L. Fundamentals of the Analytic Hierarchy Process. In The Analytic Hierarchy Process in Natural Resource and Environmental Decision Making; Springer: Berlin/Heidelberg, Germany, 2001.

53. Așchilean, I.; Giurca, I. Choosing a Water Distribution Pipe Rehabilitation Solution Using the Analytical Network Process Method. Water 2018, 10, 484. [CrossRef]

54. Hopkins, L.D. Multi-attribute Decision Making in Urban Studies. In International Encyclopedia of the Social E Behavioral Sciences; Elsevier: Amsterdam, The Netherlands, 2001; pp. 10157-10160.

55. Tavana, M.; Yazdani, M.; Di Caprio, D. An application of an integrated ANP-QFD framework for sustainable supplier selection. Int. J. Logist. Res. Appl. 2017, 20, 254-275. [CrossRef]

56. The Environmental Implementation Review. Available online: https://ec.europa.eu/environment/eir/index en.htm (accessed on 11 October 2020).

57. P. A. of C. and R. for Sustainable, Municipal Waste Management and covid-19. 2020. Available online: https://www.acrplus.org/en/municipal-waste-management-covid-19 (accessed on 2 September 2020).

58. Pereira, H.M.; Domingos, T.; Vicente, L. Portugal Millennium Ecosystem Assessment. Cent. Biol. Ambient. Fac. Ciências Univ. Lisb. 2004, 27.

59. D. de efluentes no R. Caima, Poluição do rio Caima junto à ETAR de Ossela (Oliveira de Azeméis)—Notícias de Aveiro. 2020. Available online: https:/www.noticiasdeaveiro.pt/poluicao-do-rio-caima-junto-a-etar-deossela-oliveira-de-azemeis/ (accessed on 7 September 2020).

60. Piorr, A.; Zasada, I.; Doernberg, A.; Zoll, F.; Ramme, W. Research for AGRI Committee-Urban and peri-urban agriculture in the EU; European Parliament: Brussels, Belgium, 2018.

61. Portugal Farm Tours \& Activities, Farm Tours \& Activities in Portugal | Portugal Farm Experiences. Available online: https://www.portugalfarmexperience.com/all-activities/ (accessed on 3 September 2020).

62. Delicado, A.; Figueiredo, E.; Silva, L. Community perceptions of renewable energies in Portugal: Impacts on environment, landscape and local development. Energy Res. Soc. Sci. 2016, 13, 84-93. [CrossRef]

63. Yue, H.; Zhu, X. Exploring the Relationship between Urban Vitality and Street Centrality Based on Social Network Review Data in Wuhan, China. Sustainability 2019, 11, 4356. [CrossRef] 
64. Urban Resilience and Sustainability through Peri-Urban Ecosystems: Integrating CCA and DRR. Available online: https://www.researchgate.net/publication/319877741_Urban_Resilience_and_Sustainability_ Through_Peri-urban_Ecosystems_Integrating_CCA_and_DRR (accessed on 1 September 2017).

Publisher's Note: MDPI stays neutral with regard to jurisdictional claims in published maps and institutional affiliations.

(C) 2020 by the authors. Licensee MDPI, Basel, Switzerland. This article is an open access article distributed under the terms and conditions of the Creative Commons Attribution (CC BY) license (http://creativecommons.org/licenses/by/4.0/). 